\title{
PENGARUH KOMUNIKASI PEMASARAN DAN KUALITAS PELAYANAN TERHADAP KEPUTUSAN PEMBELIAN MOBIL TOYOTA PADA PT. PUTRA PERKASA FLAMBOYAN
}

\author{
Made Adhiguna Samvara \\ Fakultas Ekonomi, Universitas Prima Indonesia \\ Jln. Sekip Simp. Sikambing Medan \\ E-mail : madegunas@gmail.com \\ diterima: 16/2/2019; direvisi: 16/3/2019; diterbitkan: 31/3/2019
}

\begin{abstract}
The development of the community's need for motorized vehicle transportation, especially for the four-wheeled type, is now unavoidable. Changes in the trend of the needs of cars not only occur globally but are experienced by automotive companies in Indonesia. The development of the needs of this car can also be felt very clearly in the people of Medan. This study aims to determine how the influence of marketing communication and service quality on Toyota car purchasing decisions and factors that have a dominant influence on Toyota car purchasing decisions at PT. Flamboyant Mighty Pioneer. The research hypothesis is marketing communication and service quality affect the Toyota car purchase decision at PT. Flamboyant Mighty Pioneer. The results showed that marketing communication and service quality had an effect on Toyota car purchasing decisions at PT. Pioneer of Flamboyant Mighty with a determination coefficient of $68.5 \%$. Marketing communication is the most dominant determining factor that can increase Toyota's car purchasing decisions at PT. Flamboyant Mighty Pioneer.
\end{abstract}

Keywords: marketing communication, service quality, purchasing decisions

\section{PENDAHULUAN}

Seiring

kebutuhan akan

perkembangannya

mobil semakin

meningkat setiap tahunnya. Hal ini terbukti pada tahun 2016 penjualan total mobil mencapai 1.061 .000 unit dan meningkat 4,5\% dari tahun 2015. (http://www.tribunnews.com/otomotif, 2017).

Sudah menjadi kebiasaan masyarakat Kota Medan dan sekitarnya, jika bekerja lebih memilih memakai transportasi pribadi daripada angkutan umum. Selain efesien oleh waktu, transportasi pribadi lebih aman dan nyaman. Merujuk dari Dirlantas Polda Sumut pada tahun 2014 dulu, jumlah kendaraan yang ada di Kota Medan mencapai 5.531.777. Dari jumlah itu, kendaraan yang tertinggi yakni sepeda motor yang mencapai 86,29 persen, mobil penumpangan 7,91 persen, mobil barang 4,50 persen dan bus mencapai 1,3 persen. Terlihat dari jumlah volume kendaraan tersebut lebih dari jumlah penduduk yang hanya 2 jutaan. (http://harian.analisadaily.com/opini/news , 2016).

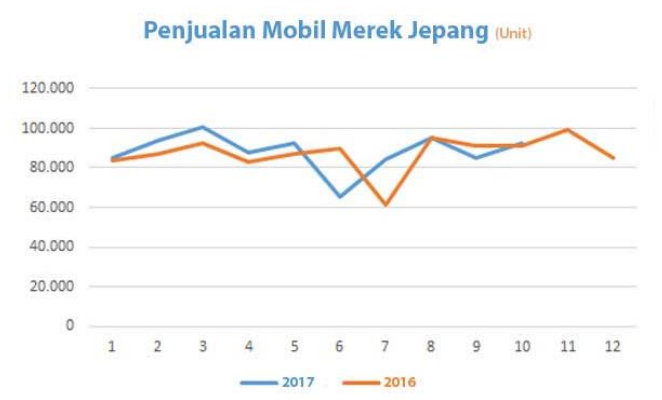

Pada Oktober 2017, penjualan mobil merek tersebut secara keseluruhan mengontribusi $97,99 \%$ pasar kendaraan bermotor beroda empat dan lebih di Indonesia. Toyota memimpin pasar dengan angka penjualan 29.938 unit atau 
mengontribusi $31,73 \%$ terhadap total penjualan nasional. (http://otomotif.bisnis.com, 2017).

PT. Perintis Perkasa Flamboyan adalah perusahaan yang bergerak dibidang otomotif yaitu kegiatan perdagangan dan maintenance mobil dengan merek Toyota yang merupakan perusahaan anak cabang dari PT. Putera Auto Perkasa yang beroperasi pada awal tahun 2013, berlokasi di Jalan Flamboyan Raya No. 66, Kelurahan Tanjung Selamat, Kecamatan Medan Tuntungan, Kota Medan, Provinsi Sumatera Utara. Lokasi tersebut yang merupakan pusat kegiatan perdagangan/bisnis dan pusat pendidikan sesuai dengan arahan Rencana Tata Ruang Wilayah Kota Medan.

Memperkenalkan perusahaan pada masyarakat luas membutuhkan strategi sehingga tujuan perusahaan tercapai dengan efektif dan efisien, melalui strategi komunikasi pemasaran yang baik maka akan meningkatkan keberhasilan dalam berusaha. Komunikasi adalah kegiatan pemasaran inti mengenai bagaimana orang menerima, mengolah dan mengerti komunikasi pemasaran, pengolahan informasi menyampaikan cara-cara dimana informasi ditransformasikan, dikurangi, dirinci, disimpan, didapatkan kembali dan digunakan.

Komunikasi adalah prasyarat kehidupan manusia melalui interaksi baik secara perseorangan, kelompok maupun organisasi, tindakan komunikasi dapat dilakukan dalam berbagai cara baik secara verbal (kata-kata lisan maupun tulisan), ataupun nonverbal (gesture, sikap, tingkah laku, gambar). Fungsi komunikasi adalah untuk menyampaikan apa yang ada di dalam benak pikirannya dan atau perasaan hatinya kepada orang lain baik secara langsung ataupun tidak langsung.
Pemasaran merupakan aktivitas perusahaan untuk memperoleh, mengembangkan dan mempertahankan konsumen, oleh karena itu pemasaran yang efektif identik dengan semakin meningkatnya loyalitas konsumen dan tumbuhnya jumlah konsumen baru yang mampu memberikan kontribusi signifikan terhadap perusahaan.

Para pengusaha yang kreatif akan selalu menciptakan kombinasi yang terbaik dari elemen yang menjadi komponen bauran pemasaran, seperti kualitas produk yang mengikuti selera konsumen di masa kini, kebijakan harga yang tepat bergantung pada daya beli masyarakat dan keadaan persaingan, perantaraan dan pemilihan saluran distribusi juga penting dengan mengandalkan promosi di media massa juga dapat dilakukan dengan memberikan diskon khusus, bonus, kontes, dan periklanan.

Terdapat bauran pemasaran yang perlu diperhatikan oleh perusahaan otomotif untuk dapat dikaji demi kelancaran dan kesuksesan suatu usaha tersebut seperti konten iklan yang dimuat pada media cetak dan billboard tidak tercantum alamat dan nomor telepon perusahaan, akun media sosial yang jarang diperbaharui, kurangnya informasi mengenai lokasi dan waktu diadakannya pameran di mall, jarang melaksanakan kegiatan sosial kemasyarakan.

Terlihat bahwa masih banyak kekurangan dalam pelaksanaan komunikasi pemasaran yang jika tidak diperbaiki kemungkinan akan berdampak kurang baik bagi perkembangan perusahaan. Berjalannya suatu perusahaan dibutuhkan komunikasi pemsaran yang baik dalam organisasi atau lembaga yang berfungsi informatif yaitu seluruh anggota suatu organisasi dan konsumen dapat memperoleh informasi yang lebih banyak, lebih baik dan tepat waktu untuk menciptakan dan memelihara hubungan sosial dan membantu 
mengurangi ketegangan dan ketidakpastian antara atasan dengan karyawan, sesama karyawan, dan juga dengan konsumen sehingga tujuan perusahaan dalam perdagangan dan maintenance mobil sesuai dengan capaian yang ditentukan.

Sebagai jasa, service umumnya mencerminkan produk tidak terwujud fisik (intangible) atau sektor industri spesifik seperti, pendidikan, kesehatan, telekomunikasi, transportasi, asuransi, perbankan, perhotelan, konstruksi perdagangan, rekreasi. Jasa merupakan aktivitas, manfaat atau kepuasan yang ditawarkan, sebagai layanan, istilah service menyiratkan segala sesuatu yang dilakukan pihak tertentu (individu maupun kelompok) kepada pihak lain. service merefleksikan proses yang mencakup penyampaian produk utama, interaksi personal, kinerja termasuk keterampilan serta pengalaman layanan. Penawaran terdiri atas barang fisik yang disertai dengan satu atau beberapa bentuk layanan guna meningkatkan daya tarik pada konsumen, seperti perusahaan mobil menawarkan layanan test drive, fasilitas pembayaran kredit, reparasi, penggantian suku cadang, dan lainnya.

Setiap organisasi pemasaran wajib menentukan secara jelas siapa konsumen yang ingin dilayani, lalu kemudian merancang dan menyampaikan strategi dan program pemasaran yang mampu memenuhi kebutuhan, keinginan, dan ekspektasi konsumen sasaran. Namun, dilapangan dalam prakteknya masih banyak ditemukan keluhan dari konsumen mengenai kualitas pelayanan yang kurang baik dalam menyampaikan informasi mengenai sistem perdagangan dan maintenance mobil tersebut.

Terdapat beberapa keluhan konsumen mengenai pelayanan yang kurang baik diantaranya, kurang berlanjutnya komunikasi yang baik antara marketing dan konsumen setelah pembelian mobil mengenai promosi terbaru dan informasi service selanjutnya, kurangnya informasi mengenai terbitnya surat tanda nomor kendaraan bermotor (STNK) dan buku pemilik kendaraan bermotor (BPKB) serta kesalahan perbaikan kerusakan mobil.

Keluhan-keluhan tersebut yang dirasakan oleh konsumen harus menjadi perhatian serius bagi perusahaan karena dalam hal ini konsumen sebagai pembeli hanya dijadikan target untuk mengambil keuntungan tanpa memperhatikan hubungan selanjutnya untuk dapat menjadi pelanggan secara tidak langsung sebagai penyalur informasi ke orang lain untuk pengenalan perusahan lebih luas. Ketidakseriusan perusahaan dalam menaggapi keluhan tersebut akan berdampak tidak baik bagi perusahaan.

Tabel 1 Daftar Target Pencapaian Penjualan Bulan Januari Desember 2017 Pada PT. Perintis Perkasa Flamboyan

\begin{tabular}{|l|l|l|l|c|}
\hline No & Bulan & \multicolumn{1}{|c|}{ Penjualan } & Target pencapaian & $\begin{array}{c}\text { Persenta } \\
\text { se }\end{array}$ \\
\hline 1 & Januari & Rp. 8.801 .260 .000 & Rp. 14.953 .670 .000 & $58,9 \%$ \\
\hline 2 & Februari & Rp. 11.309 .690 .000 & Rp. 13.828 .937 .000 & $81,2 \%$ \\
\hline 3 & Maret & Rp. 14.309 .690 .000 & Rp. 13.220 .350 .000 & $108,2 \%$ \\
\hline 4 & April & Rp. 13.284 .341 .000 & Rp. 12.634 .179 .000 & $105,1 \%$ \\
\hline 5 & Mei & Rp. 15.368 .256 .000 & Rp. 15.222 .633 .000 & $101,0 \%$ \\
\hline 6 & Juni & Rp. 11.482 .103 .000 & Rp. 15.479 .837 .000 & $74,2 \%$ \\
\hline 7 & Juli & Rp. 11.776 .540 .000 & Rp. 13.140 .479 .000 & $89,6 \%$ \\
\hline 8 & Agustus & Rp. 15.123 .827 .000 & Rp. 12.425 .479 .000 & $121,7 \%$ \\
\hline 9 & September & Rp. 9.163 .409 .000 & Rp. 11.838 .904 .000 & $77,4 \%$ \\
\hline 10 & Oktober & Rp. 9.814 .640 .000 & Rp. 11.693 .604 .000 & $83,9 \%$ \\
\hline 11 & November & Rp. 20.674.174.000 & Rp. 12.497 .728 .000 & $165,4 \%$ \\
\hline 12 & Desember & Rp. 15.230 .491 .000 & Rp. 13.452 .437 .000 & $113,2 \%$ \\
\hline
\end{tabular}

Sumber: PT. Perintis Perkasa Flamboyan, 2017

Berdasarkan tabel tersebut di atas terlihat bahwa penjualan pada tahun 2017 terdapat 6 (enam) kali pencapaian target yaitu bulan Maret sebesar 108,2\%, bulan April sebesar 105,1\%, bulan Agustus sebesar $121,7 \%$, bulan November sebesar $165 \%$ dan bulan Desember sebesar $113 \%$. Namun sebanyak 6 (enam) bulan menunjukkan bahwa penjualan tidak mencapai target yang ditentukan yaitu dengan persentase penjualan pada bulan 
Januari sebesar $58,9 \%$, pada bulan Februari sebesar $81,2 \%$, pada bulan Juni sebesar $74,2 \%$, pada bulan Juli sebesar $89,6 \%$, dan pada bulan Oktober sebesar $83,9 \%$.

Berdasarkan fenomena-fenomena yang terjadi di atas merupakan permasalahan yang dihadapi konsumen dan juga perusahaan tentang pengaruh komunikasi pemasaran dan kualitas pelayanan terhadap keputusan pembelian mobil Toyota pada PT. Perintis Perkasa Flamboyan

\section{TINJAUAN PUSTAKA}

Fajar (2009:34) mendefinisikan komunikasi adalah proses pernyataan antarmanusia mengenai pikiran atau perasaan kepada orang lain dengan menggunakan bahasa sebagai alat penyalurnya.

Buchari Alma (2016:185)

menyatakan pemasaran berarti kegiatan yang dilakukan oleh perusahaan untuk menyiapkan, memberi harga, mendistribusikan dan mempromosikan produknya atau jasanya ke konsumen.

Komunikasi

pemasaran

merupakan aktivitas pemasaran yang berusaha menyebarkan informasi, mempengaruhi/membujuk dan mengingatkan pasar sasaran atas perusahaan dan produknya agar bersedia menerima, membeli dan loyal pada produk yang ditawarkan perusahaan yang bersangkutan. (Uyung Sulaksana dalam buku Priansa, 2017:96)

Priansa (2017:98) menyatakan bahwa elemen promosi dan pemasaran lainnya disebut dengan bauran komunikasi pemasaran yang terdiri atas:

1. Periklanan (advertising) merupakan setiap bentuk komunikasi nonpersonal tentang produkyang dihasilkan oleh perusahaan, baik barang maupun jasa.

2. Pemasaran langsung (direct marketing) merupakan pemasaran dengan cara membina hubungan yang sangat dekat target market yang memungkinkan terjadinya proses komunikasi dua arah menggunakan berbagai saluran komunikasi.

3. Promosi penjualan (sales promotion) merupakan segal amacam bentuk komunikasi persuasi yang dirancang untuk menginformasikan pelanggan tentang produk atau jasa dan mempengaruhi mereka agar mereka barang atau jasa yang dihasilkan oleh perusahaan.

4. Penjualan personal (personal selling) merupakan suatu bentuk komunikasi langsung antara penjual dan calon pembelinya, dalam hal ini penjual berupaya untuk membantu atau membujuk calon pembeli untuk membeli produk yang ditawarkan.

5. Pemasaran interaktif (interactive marketing), konsep Integrated Marketing Communication (IMC) adalah komunikasi dua arah yang difasilitasi melalui penggunaan event, sponsor dan pameran dagang serta situs web secara lebih besar.

6. Perusahaan merencanakan dan mendistribusikan informasi secara sistematis dalam upaya mengontrol dan mengelola citra serta publisitas yang diterimanya.

Menurut Tjiptono (2008: 15) menyatakan bahwa jasa/layanan merupakan perbuatan, tindakan, pengalaman, proses, kinerja (performance) atau usaha yang sifatnya abstrak, layanan jasa hanya bisa dikonsumsi tetapi tidak dapat dimiliki (non-ownership). Mereka akan menyimpulkan kualitas jasa dari aspek tempat (place), orang (people), peralatan (equipment), bahan dan materi komunikasi (comunication materials), simbol (symbol) dan harga (price) yang mereka amati. Hal sebagai berikut bisa dipertimbangkan: 
Jurnal Ilmiah Ekonomi dan Bísnis

Vol. 16. No.1, Maret 2019: 56-66

EISSN : $2442-9813$

ISSN : $1829-9822$

a. Manajemen bukti fisik contoh parkir eskslusif, elektronic bussines card, dapur terbuka.

b. Personalia layanan yaitu dengan cara memanfaatkan sumber daya personal lebih banyak dibandingkan sumber daya lainnya. Layanan yang bersifat personal berpotensi memantapkan keyakinan mereka untuk melakukan pembelian.

c. Manajemen komunikasi getok tular, upaya menstimulasi atau mendorong komunikasi getok tular (word of mouth communication), misalnya memberikan insentif tertentu kepada setiap pelanggan yang dapat menarik pelanggan baru bagi perusahaan.

d. Manajemen citra korporat, menciptakan citra organisasi yang kuat, konsisten, dan terintegrasi melalui iklan, logo/simbol, prilaku manajemen dan karyawan yang positif (responsif, etis, peduli akan lingkungan dan isu sosial, terpercaya).

e. Manajemen biaya dengan cara mengimplementasikan manajemen dan akuntansi biaya secara efektif dalam rangka mendukung penetapan harga seakurat mungkin sehingga bisa menutupi biaya, menghasilkan tingkat laba sesuai harapan, terjangkau dan sesuai dengan daya beli dan kesediaan pelanggan untuk membayar sekaligus kompetitif sesuai dengan peraturan yang berlaku.

f. Manajemen komunikasi purnabeli, diantaranya mengumpulkan informasi berkenaan dengan kepuasan pelanggan, keluhan pelanggan, saran dan kritik pelanggan, serta menyampaikan informasi produk, jasa baru dan program promosi baru kepada mereka. Hal ini berpotensi untuk mendukung terciptanya cross selling (menjual produk lain kepada pelanggan yang sama), up selling (menawarkan versi produk sejenis yang lebih mahal) dan pertumbuhan bisnis lainnya di masa depan. Tjiptono (2008:16)

Zeithaml et al (dalam buku Djohan, 2016:23) mengatakan bahwa kualitas pelayanan merupakan indikator terpenting dari penjual, aspek dari kualitas layanan yang terkenal yaitu: Reliable, Assurance, Tangible, Empathy, Responsiveness (dapat dipercaya, jaminan, bukti fisik, empati dan cepat tanggap).

Ristiayanti dan John (2005:226) menyatakan bahwa keputusan sebagai suatu pemilihan tindakan dari dua atau lebih pilihan alternatif, orang mengambil keputusan harus mempunyai satu pilihan dari beberapa alternatif yang ada.

Faktor internal yang menggerakkan dan mempengaruhi perilaku:

1. Sumber daya konsumen, setiap orang membawa tiga sumber daya ke dalam setiap situasi pengambilan keputusan, waktu, uang dan perhatian (penerimaan informasi dan kemampuan pengolahan). Umumnya terdapat keterbatasan yang jelas pada ketersediaan masing-masing, sehingga memerlukan semacam alokasi yang cermat

2. Motivasi dan keterlibatan, benda-benda yang orang beli dipandang mempunyai makna pribadi dan sosial selain fungsi mereka, Barang modern dikenali sebagai benda psikologis, sebagai simbol dari sifat dan tujuan pribadi, sebagai simbol dari pola dan perjuangan sosial. Contoh bobot yang ringan, kemudahan penggunaan, kemudahan penyimpanan

3. Pengetahuan, pengetahuan konsumen mencakup susunan luas informasi, 
seperti ketersediaan dan karakteristik produk dan jasa, dimana dan kapan untuk membeli dan bagaimana menggunakan produk. Pentingnya pengertian pengetahuan atau keahlian konsumen ditekankan lagi dalam bidang penelitian konsumen, salah satu hasil peiklanan dan penjualan adalah benar-benar memberikan pengetahuan dan informasi yang relevan, khususnya di bawah pemecahan masalah yang diperluas.

4. Sikap pembentukan sikap terhadap alternatif yang dipertimbangkan, sikap dikonseptualisasikan sebagai perasaan positif atau negatif terhadap merek dan dipandang sebagai hasil dari penilaian merek bersama dengan kriteria atribut evaluatif yang terpenting.

Kepribadian bahwa produk juga mempunyai kepribadian dalam bentuk citra merek. Suatu deduksi logis pada titik.

\section{METODE PENELITIAN}

Penelitian ini menggunakan pendekatan kuantitatif. Menurut Rakhmat (2004:24) analisis kuantitatif menggambarkan berbagai analisis statistik, bermacam alat ukur, procesing data dan analisis isi. Dalam analisis data digunakan uji statistik, alat ukur yang digunakan memenuhi prinsip reliabilitas dan validitas, dengan sifat penelitian adalah explanatif. Menurut Kriyantono(2007:61) survei eksplanatif menjelaskan hubungan antara dua atau lebih variabel, membuat hipotesis sebagai asumsi awal untuk menjelaskan hubungan antarvariabel yang diteliti.

Variabel penelitian ini terdiri dari variabel bebas yaitu komunikasi pemasaran $\left(\mathrm{X}_{1}\right)$, kualitas pelayanan $\left(\mathrm{X}_{2}\right)$ dan variabel terikat adalah keputusan pembelian (Y), variabel-variabel penelitian ini akan diturunkan menjadi indikator untuk dapat merancang instrumen penelitian yaitu pertanyaanpertanyaan dalam kuesioner. Kuesioner yang dirancang menggunakan skala pengukuran dengan metode skala Likert, dengan opsi jawaban sebanyak 5 (lima) pilihan $(5,4,3,2,1)$.

Populasi dalam penelitian ini adalah konsumen yang melakukan pembelian mobil Toyota di perusahaan Perintis Perkasa Flamboyan pada Bulan Januari-Desember 2017 sebanyak 696 konsumen.

Jenis sampling yang digunakan adalah accidental sampling yaitu pengambilan sampel dengan cara kebetulan yaitu responden yang membeli mobil Toyota dan melakukan perbaikan (service) di PT. Perintis Perkasa Flamboyan Medan. Jumlah sampel yang diambil adalah 254 responden.

Kuesioner yang telah dirancang sebelum dibagikan kepada responden penelitian maka akan dilakukan pengujian validitas dan reabilitas dengan membagikan kuesioner kepada 30 orang responden diluar dari sampel penelitian. Kuesioner yang telah valid dan reliabel dapat langsung dibagikan kepada 254 responden. Kuesioner yang telah diisi oleh responden maka datanya akan diinput untuk dilakukan pengujian asumsi klasik dan kemudian dilakukan analisis data dengan menggunakan metode analisis statistik deskriptif dan analisis regresi berganda.

\section{HASIL DAN PEMBAHASAN}

Berdasarkan hasil pengujian regresi berganda tersebut maka model penelitian ini diperoleh sebagai berikut: $\mathrm{Y}=5,648+0,559 \mathrm{X}_{1}+0,585 \mathrm{X}_{2}$

Tabel 2.: Hasil Uji Model Analisis Penelitian 


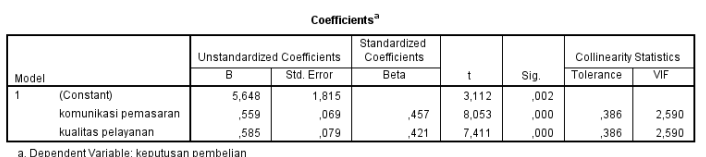

Model persamaan regresi di atas dapat diinterpretasikan bahwa konstanta sebesar 5,648 memiliki makna bahwa jika nilai variabel bebas yaitu komunikasi pemasaran dan kualitas pelayanan adalah nol atau dianggap tidak ada maka nilai keputusan pembelian adalah 5,648 satuan.

Komunikasi pemasaran $\left(\mathrm{X}_{1}\right)$ mempunyai koefisien regresi sebesar 0,559 dan bernilai positif, hal ini berarti setiap kenaikan satu satuan variabel komunikasi pemasaran maka akan meningkatkan keputusan pembelian sebesar 0,559 satuan, jika variabel lain diasumsikan konstan. Hal ini memberikan penjelasan bahwa komunikasi pemasaran merupakan bagian yang perubahannya searah dengan keputusan pembelian.

Kualitas pelayanan mempunyai koefisien regresi sebesar 0,585 dan bernilai positif, hal ini berarti setiap kenaikan satu satuan.

variabel kualitas pelayanan maka akan meningkatkan keputusan pembelian sebesar 0,585 satuan, jika variabel lain diasumsikan konstan. Hal ini memberikan penjelasan bahwa kualitas pelayanan merupakan bagian yang perubahannya searah dengan keputusan pembelian.

Berdasarkan hasil pengujian diatas dapat dilihat bahwa nilai $\mathrm{R}^{2}$ sebesar 0,688 dan nilai Adjusted $\mathrm{R}^{2}$ sebesar 0,685 yang memiliki arti bahwa variasi variabel komunikasi pemasaran dan kualitas pelayanan mampu menjelaskan 68,5\% variasi variabel keputusan pembelian sedangkan sisanya sebesar $32,5 \%$ dijelaskan oleh variabel lain yang tidak diteliti oleh penelitian ini.

Pengujian secara simultan atau uji $\mathrm{F}$ bertujuan untuk melihat bagaimana pengaruh komunikasi pemasaran dan kualitas pelayanan terhadap keputusan pembelian mobil Toyota PT. Perintis Perkasa Flamboyan. Berdasarkan hasil uji di atas maka diperoleh nilai $F_{\text {hitung }}$ sebesar 276,245 dan nilai signifikansi sebesar 0,000. Nilai $F_{\text {hitung }}$ akan dibandingkan dengan nilai $F_{\text {tabel }}$ yaitu sebesar 2,21 (diperoleh melihat $\mathrm{F}_{\text {tabel }}$ dengan kriteria df1=5 dan df2 lebih besar dari 200), maka hasil yang diperoleh adalah $F_{\text {hitung }}>F_{\text {tabel }}$ $(2,21)$ serta nilai signifikansi $0,000<0,005$ sehingga dapat disimpulkan bahwa komunikasi pemasaran dan kualitas pelayanan berpengaruh terhadap tingkat keputusan pembelian mobil toyota pada PT. Perintis Perkasa Flamboyan.

Hasil penelitian telah menunjukkan bahwa komunikasi pemasaran dan kualitas pelayanan berpengaruh terhadap pencapaian tingkat keputusan pembelian mobil Toyota pada PT. Perintis Perkasa Flamboyan, dengan demikian seluruh variabel komunikasi pemasaran yang ada yaitu periklanan, pemasaran langsung, promosi penjualan, penjualan personal, pemasaran interaktif, hubungan masyarakat dan seluruh variabel kualitas pelayanan yang ada yaitu reliabel, assurance, tangibel, responsiveness, empathy merupakan bagian yang harus terus diperhatikan dan dikembangkan untuk semakin lebih baik sehingga dapat memberikan peningkatan keputusan pembelian mobil Toyota.

Komunikasi pemasaran yang dilakukan harus dapat terukur sehingga dapat diketahui pencapaian akhir dari sebuah proses pemasaran yang telah dilakukan. Untuk mengukur komunikasi pemasaran, Priansa (2017:98) menyatakan bahwa elemen promosi dan pemasaran lainnya disebut dengan bauran komunikasi pemasaran yang terdiri atas:

1. Periklanan (advertising) merupakan setiap bentuk komunikasi nonpersonal tentang produkyang dihasilkan oleh perusahaan, baik barang maupun jasa. 
2. Pemasaran langsung (direct marketing) meruapakan pemasaran dengan cara membina hubungan yang sangat dekat target market yang memungkinkan terjadinya proses komunikasi dua arah menggunakan berbagai saluran komunikasi.

3. Promosi penjualan (sales promotion) merupakan segal amacam bentuk komunikasi persuasi yang dirancang untuk menginformasikan pelanggan tentang produk atau jasa dan mempengaruhi mereka agar mereka barang atau jasa yang dihasilkan oleh perusahaan.

4. Penjualan personal (personal selling) merupakan suatu bentuk komunikasi langsung antara penjual dan calon pembelinya, dalam hal ini penjual berupaya untuk membantu atau membujuk calon pembeli untuk membeli produk yang ditawarkan.

5. Pemasaran interaktif (interactive marketing), konsep Integrated Marketing Communication (IMC) adalah komunikasi dua arah yang difasilitasi melalui penggunaan event, sponsor dan pameran dagang serta situs web secara lebih besar.

6. Perusahaan merencanakan dan mendistribusikan informasi secara sistematis dalam upaya mengontrol dan mengelola citra serta publisitas yang diterimanya.

Zeithaml et al (dalam buku Djohan, 2016:23) mengatkan bahwa kualitas pelayanan merupakan indikator terpenting dari penjual, aspek dari kualitas layanan yang terkenal yaitu:

1. Reliable yakni kemampuan memberikan layanan yang dijanjikan dengan segera, akurat dan memuaskan

2. Assurance mencakup pengetahuan, kompetensi, kesopanan, dan sifat dapat dipecaya yang dimiliki para karyawan, bebas dari bahaya fisik, resiko, keragu-raguan.

3. Tangible meliputi fasilitas fisik, perlengkapan, karyawan, dan sarana komunikasi yang tersedia dengan baik.

4. Empathy meliputi kemudahan dalam menjalin hubungan, komunikasi yang efektif, perhatian personal, dan pemahaman terhadap kebutuhan individual para konsumen.

5. Responsiveness (dapat dipercaya, jaminan, bukti fisik, empati dan cepat tanggap).

Peneliti telah membatasi penelitian pada 6 (enam) faktor komunikasi pemasaran dan 5 (lima) faktor kualitas pelayanan yang diasumsikan memberikan pengaruh terhadap keputusan pembelian mobil Toyota Perintis Perkasa Flamboyan. Berdasarkan berbagai referensi buku teori manajemen pemasaran dan jurnal penelitian terdahulu maka peneliti mendapatkan 6 (enam) faktor komunikasi pemasaran yaitu:

1. Periklanan (advertising) merupakan setiap bentuk komunikasi nonpersonal tentang produkyang dihasilkan oleh perusahaan, baik barang maupun jasa.

2. Pemasaran langsung (direct marketing) meruapakan pemasaran dengan cara membina hubungan yang sangat dekat target market yang memungkinkan terjadinya proses komunikasi dua arah menggunakan berbagai saluran komunikasi.

3. Promosi penjualan (sales promotion) merupakan segal amacam bentuk komunikasi persuasi yang dirancang untuk menginformasikan pelanggan tentang produk atau jasa dan mempengaruhi mereka agar mereka barang atau jasa yang dihasilkan oleh perusahaan.

4. Penjualan personal (personal selling) merupakan suatu bentuk komunikasi langsung antara penjual dan calon pembelinya, dalam hal ini penjual berupaya untuk membantu atau membujuk calon pembeli untuk 
membeli produk yang ditawarkan.

5. Pemasaran interaktif (interactive marketing), konsep Integrated Marketing Communication (IMC) adalah komunikasi dua arah yang difasilitasi melalui penggunaan event, sponsor dan pameran dagang serta situs web secara lebih besar.

6. Perusahaan merencanakan dan mendistribusikan informasi secara sistematis dalam upaya mengontrol dan mengelola citra serta publisitas yang diterimanya.

Dan 5 (lima) faktor kualitas pelayanan yaitu:

1. Reliable yakni kemampuan memberikan layanan yang dijanjikan dengan segera, akurat dan memuaskan

2. Assurance mencakup pengetahuan, kompetensi, kesopanan, dan sifat dapat dipecaya yang dimiliki para karyawan, bebas dari bahaya fisik, resiko, keragu-raguan.

3. Tangible meliputi fasilitas fisik, perlengkapan, karyawan, dan sarana komunikasi yang tersedia dengan baik.

4. Empathy meliputi kemudahan dalam menjalin hubungan, komunikasi yang efektif, perhatian personal, dan pemahaman terhadap kebutuhan individual para konsumen.

5. Responsiveness (dapat dipercaya, jaminan, bukti fisik, empati dan cepat tanggap).

Peneliti akan melanjutkan untuk menguji dari keenam faktor komunikasi pemasaran dan kelima faktor kualitas pelayanan tersebut agar diketahui faktor mana merupakan faktor dominan yang mempengaruhi keputusan pembelian mobil Toyota.

Hasil pengujian yang dilakukan dengan uji t maka dapat diketahui faktor mana yang dominan yang mempengaruhi keputusan pembelian mobil Toyota adalah komunikasi pemasaran $\left(\mathrm{X}_{1}\right)$ dengan nilai $t_{\text {hitung }}=8,053$. Variabel komunikasi pemasaran yang tercermin dari enam indikator yaitu periklanan, pemasaran langsung, promosi penjualan, penjualan personal, pemasaran interaktif, hubungan masyarakat. Keenam indikator tersebut kemudian dipecah menjadi 12 (dua belas) pernyataan dalam kuesioner penelitian yaitu:

1. Produk/promosi yang ditawarkan melalui iklan pada media massa seperti billboard, koran, spanduk, brosur dalam memberikan informasi yang lengkap bagi konsumen

2. Produk yang ditawarkan melalui iklan pada media sosial seperti facebook, instagram, website untuk memberikan informasi yang lengkap bagi konsumen

3. Perusahaan memiliki gedung untuk menjajakan produk yang dijual

4. Perusahaan melakukan penawaran produk secara langsung melalui pameran di Mall

5. Berbagai promosi yang ditawarkan perusahaan sesuai dengan kebutuhan konsumen

6. Berbagai promosi yang ditawarkan perusahaan memberikan kemudahaan bagi konsumen

7. Perusahaan menugaskan marketing untuk menawarkan produk kepada konsumen

8. Informasi produk disampaikan dengan jelas oleh marketing

9. Perusahaan menggunakan internet (whatsap) dalam bertukar informasi mengenai dengan konsumen

10. Perusahaan menggunakan internet (email) dalam bertukar informasi mengenai produk dengan konsumen

11. Perusahaan terlibat dalam berbagai kegiatan kemasyarakatan seperti bakti sosial.

12. Perusahaan memperingati hari besar 
keagamaan dan hari besar nasional

Dengan demikian terlihat jelas bahwa persepsi masyarakat yang tertinggi tentang keputusan pembelian mobil Toyota terletak pada variabel komunikasi pemasaran sehingga perusahaan harus lebih baik mengelola dan meningkatkan komunikasi pemasaran yang dimiliki sebagai upaya peningkatan keputusan pembelian mobil Toyata pada PT. Perintis Perkasa Flamboyan.

\section{KESIMPULAN DAN SARAN}

Berdasarka hasil penelitian menunjukkan komunikasi pemasaran dan kualitas pelayanan berpengaruh terhadap keputusan pembelian mobil Toyota pada PT. Perintis Perkasa Flamboyan dengan koefisien determinasi sebesar 68,5\%. Komunikasi pemasaran merupakan faktor penentu yang paling dominan yang dapat meningkatkan keputusan pembelian mobil Toyota pada PT. Perintis Perkasa Flamboyan.

\section{DAFTAR PUSTAKA}

Alma, Buchari. 2016. Kewirausahaan: Untuk Mahasiswa dan Umum. Edisi Revisi. Alfabeta. Bandung

Djohan, Agustinus Johanes. 2016. Manajemen dan Strategi Pembelian. Media Nusa Creative. Malang

Engel, James F, Roger D Blackwell dan Paul W Miniard. 1994. Perilaku konsumen: Edisi Keenam. Jilid 1. Binarupa Aksara. Jakarta

Fajar, Marhaeni. 2009. Ilmu Komunikasi: Teori \& Praktek. Edisi Pertama. Grahallmu. Yogyakarta
Kriyantono, Rachmat. 2007. Teknik Praktis Riset Komunikasi:Disertai Contoh Praktis Riset Media, Public Relations, Advertising, Komunikasi Organisasi, Komunikasi Pemasaran. Edisi Pertama. Kencana. Jakarta

Noor, Juliansyah. 2011. Metodologi Penelitian: Skripsi, Tesis, Disertasi dan Karya Ilmiah. Kencana. Jakarta

Prasetyo, Ristiayanti dan John J.O.I Ihalauw. 2005.Perilaku Konsumen. Andi. Malang

Priansa, Donni Juni. 2017. Komunikasi Pemasaran Terpadu: Pada Era Media Sosial. Bandung. CV Pustaka Setia

Rakhmat, Jalaluddin.2004. Metode Penelitian Komunikasi:Dilengkap Contoh Analisis Statistik. PT Remaja Rosdakarya. Bandung

Sunyoto, Danang. 2014. Konsep Dasar Riset Pemasaran dan Perilaku Konsumen. Center for Academic Publishing. Yogyakarta

Tjiptono, Fandy. 2008. Service Management: Mewujudkan Layanan Prima. CV Andi Offset.Yogyakarta

Winardi, J. 2003. Entrepreneur dan entrepreneurship: Edisi Pertama. Kencana. Jakarta

Hendri, Meriza. 2009. 'Pengaruh Komunikasi Pemasaran terhadap Keputusan Pembelian Teh Kotak Ultra rasa melati oleh remaja di Kota Bandung',. The 3rd National Conference Research. Issn 2086-0390 
Meliana, Sulistiono dan Budi Setiawan. 2013. Pengaruh Kualitas Pelayanan dan Kepercayaan Konsumen Terhadap Keputusan Pembelian: studi kasus pada Giant hypermarket. Jurnal Ilmiah Manajemen Kesatuan Vol. 1 No. 3

Pratiwi, Made Prajna, I Wayan Suwendra dan $\mathrm{Ni}$ Nyoman Yulianthini. 2015. 'Pengaruh Strategi Komunikasi Pemasaran Terhadap Keputusan Pembelian Sepeda Motor Honda', e-Journal Bisma Universitas Pendidikan Ganesha Jurusan Manajemen. Volume 3
Sejati, Bayu Sutrisna Sejati. 2016. Pengaruh Kualitas Produk, Kualitas Pelayanan, Dan Harga Terhadap Keputusan Pembelian Pada Starbucks. Jurnal Ilmu dan Riset Manajemen : Volume 5, Nomor 3

http://www.tribunnews.com/otomotif, 2017 $\mathrm{http} / / /$ harian.analisadaily.com/opini/news, 2016

http://otomotif.bisnis.com, 2017 